\title{
Imaginary Vs. Traditional Museum: The Historical Heritage-Based Design
}

\author{
Yuke Ardhiati $^{1 *}$, Ashri Prawesthi D ${ }^{2}$, L.Edhi Prasetya ${ }^{3}$, Febri Kurniawan ${ }^{4}$ \\ ${ }^{1,2,3}$ Architecture Department, Pancasila University, Jakarta, Indonesia \\ ${ }^{4}$ Adicitta Studio Architects, Jakarta, Indonesia \\ *Corresponding author. Email: yukeardhiati@gmail.com
}

\begin{abstract}
This study is qualitative research that was concerned in a museum of the millennials' age. By a comparison study between a traditional museum "De Tjolomadoe" and an imaginary of Soekarno's virtual museum was found the similarities and differences scheme. "De Tjolomadoe" as a traditional museum shows the giant machines artifacts as the iconic of museum collections, and the Soekarno's Virtual Museum shows the imaginary of postmodern architecture building to shows the maestro of artist paintings as the Soekarno's collections. Both traditionally and virtually created based on historical heritages. However, the virtual museum is the best solution to cut off the major construction budgets and rare museum collections. By a collaboration on multidisciplinary sciences, historical archives, architectural science, and digital application, a virtual museum as a video model of the imaginary museum building contained the historical archives that suitable for millennials as it is easy to access everywhere and anytime in the cyberspace.
\end{abstract}

Keywords: De Tjolomadoe, cyberspace, digital application, video of the imaginary museum, Soekarno's virtual museum

\section{INTRODUCTION}

Virtual Museum was born when the traditional museum cannot directly reach for visitors. Due to the reasons, the traditional museum then modified their collections into digital in order public easily to access. Both virtual and traditional museum has a role in showing the museum artifacts in two ways, digitally and physically. The National Museum of Indonesia is one of the museums that have a traditional and virtual museum named Museum National Virtual Tour [1]. It shows the museum building in cyberspace through 3D images. The virtual museum is known as a digital entity that draws on the characteristics of a museum. It is made to complement, enhance, or augment the museum through personalization, interactivity, user experiences, and richness of content and is connected with social media for easy access from the public [2].

Meanwhile, by visiting a traditional museum, visitors felt a new spatial experience, especially its design and a uniqueness architecture 'form'. On the other hand, visiting the museum building may have the visiting procedures, have to pay and queue. Sometimes, the public is not permitted to visit for security reasons. In special cases, visitors have not spare time to go; they will miss the opportunities to visit the museum. Due to this reason, then several museums started to create a virtual museum as a creative solution that shows the collections through a digital application.

In the last definition, the museum is related to the silent building and located in the old heritage building performance. However, after The Solomon R.
Guggenheim Museum was built in 1943, all museums were modified into attractive buildings. Until now, the prominent museum of postmodern architecture has a role as the benchmarking among others; (a) The Solomon R. Guggenheim Museum of New York City, designed by Frank Wright Lloyd, (b) the New Acropolis Museum of Athens, designed by Bernard Tschumi, (c) The Guggenheim Museum of Bilbao, designed by Frank Gehry and (d) The National Museum of Australia of Canberra, designed by Ashton Raggatt McDougall and Robert Peck von Hartel Trethowan [3].

Nevertheless, the classical museum buildings are still as attractive as a tourist destination. They are well known as the museum of historical heritages among others; (1) the Vatican Museum of Rome, (2) the Hagia Sofia of Istanbul, (3) the Egypt Museum of Cairo, (4) the Greek Museum of Athena, (5) the Sagrada Familia, of Barcelona, (6) the Louvre Museum of Paris, (7) and the Trocadero Museum of Architecture of Paris [4].

Recently, the Ministry of Education and Culture manages around more than 400 Indonesian museums. They used the heritage guidelines resulting in the limitation regarding the museum design. According to the author, with such restrictions, visitors often perceive the final design to be "gloomy" or "boring", which is hardly an incentive to visit a museum to see what appears to be leftover displays. [5] It is particularly ironic since the museum exists to reflect the highest degree of a nation's civilization. President Susilo Bambang Yudhoyono started to museum reform initiative called, "Love Our National Museums Movement", under the auspices of the "Visit Indonesia Museums" (2010-2014) project. [6] 


\subsection{The First Case "De Tjolomadoe"}

De Tjolomadoe" museum in Karanganyar of Central Java is one of the traditional museums using an old heritage building. The building is initially a sugar factory building and in the registration process of a Historical Building [7]. "De Tjolomadoe" museum was created to connect historical distances and trajectories of the Colonial era by exposing the archeological artifacts and textual descriptions. "De Tjolomadoe" is a part of the Convention and Heritage building of PG. Colomadu after revitalization in the 2017s [8].

Before it was nationalized in 1946, the "suiker fabriek of Tjolomadoe" is a prominent sugar factory owned and built by KPAA-Kanjeng Pangeran Adipati Arya Mangkunegara IV at 1861. The original building has an Indies Architecture style. The old factory of Tjolomadoe, according to KLTV archives documentation in the 1867s, is characterized by (a) a porch (b) Tuscany's column, (c) the pyramid roof or gable roof [9]. After he died, the factory is continued by his grandson. The reformation of this factory was held in 1927. According to Soerabaia magazine in the 1937s, His Grandson (KPAA Mangkunegara VII) has developed the old factory by investing in modern sugar machines [10]. Then, the giant sugar machines are brought in. Because of that, then the factory was developed with a high ceiling, high entrance gate, and the need for an entrance to the road. At the same time, he also inserted the old one to be an Art Deco façade. Then, the sugar factory performs its role in generating economic values as the great sugar factory in Java.

Even though he was a wealthy noble, His Grandson always remembers the original messages of His Grandfather (KPAA Mangkunegara IV) to all sugar factory laborers in the Javanese language; "Pabrik iki dibangun ora kanggo nyugihi, ananging nguripi, mula openono". This phrase means: "The sugar factory was built not to make it rich but to "give a life" so please to protect it [11].

Early in the Independence era, it was nationalized by the Indonesian Government based on Soerat Koeasa Istimewa on behalf of His Grandson II, KPAA Mangkunegara VIII in the1946s [12]. During ownership by the Indonesia Republic, the sugar factory was declining and closed forever at the moment of the Indonesian Reform era in 1998.

Unfortunately, for more than 20 years, the entire heritage buildings were damaged, including its whole architectural documents [13]. However, even when the factory was closed, the collective memories of the suiker fabriek of Tjolomadoe's stakeholders are still intact. During the Joko Widodo era, the old building was revitalized in 2017-2018. The new "De Tjolomadoe" Conventional and Heritage Museum was owned by BUMN of Indonesian. With the BUMN mission and role to generate economic value, "De Tjolomadoe" is expected to be a cultural venue in Central Java. By inserting "De" in front of "Tjolomadoe" is means the management dreams the new building to be as glorious as the suiker fabriek in the Colonial era.

\subsection{The Second Case}

Meanwhile, Soekarno's Virtual Museum is a video of an imaginary museum building created to show Soekarno's painting's collection series. It created based on archival data of book collections. During his life, Soekarno was loved to collect many masterpiece paintings and sculptures from famous artists in the world to beautify the Presidential Palaces in Jakarta, Bogor, Cipanas, Yogyakarta and Bali. Now, his art collection cannot be accessible for the public because it located inside the Presidential Palaces. The painting collections look like a museum gallery that beautifies the Presidential Palaces. [13].

Because of his extensive paintings collections, his legacy is needed as a learning media for millennials who studies in art and architecture. According to Soekarno's biography book, he once ordered: "That all of his collection be seen by all Indonesian people so that his/her heart can feel the beauty to inspire their beautiful mind." [14]. Then, he asked Dullah (1956) and Lee Man Fong (1964), the Presidential Palace Curators, to compile his collections to be published in a book, and three books were published. Two series in 1956 were published in Peking, and four series were compiled by Dullah. Then, the 5 (five) series was published in 1964 by Toppan of Tokyo, Japan [15]. The painting and sculpture collections book of Soekarno was the most popular book until now and acted as the primary resource to Indonesian artists who study in painting [16]. All the original collections are kept inside the 6 (six) Presidential Palaces, and the public cannot give their appreciation without formal permission. Fortunately, Yogyakarta Palaces and Tampak Siring of Bali have started to open their collections. However, it is only a small part of his whole ownership. The museum shows various collections of all Indonesian Presidents.

During August 2016-2018, to commemorate the $71 \mathrm{st}$ Anniversary of Indonesia's Independence, the Secretary Minister of the Presidential Palace had created a temporary exhibition of its art collection. The first was held to allow the people to enjoy and to marvel at the Palace's art collection entitled "1771: The Brushstrokes of the Struggle for Independence" - Goresan Juang Kemerdekaan showcasing 28 artworks from Soekarno's art collection curated by Mikke Susanto and Rizki A Zaelani [17]. The second was in 2017 named "Senandung Ibu Pertiwi" (Our Motherland's Melody), curated by Asikin Hasan, Amir Sidharta, and Selly Texania [18]. Furthermore, the third in 2018 titled "Indonesia Semangat Dunia" (Indonesia Spirit of the World) was curated by Amir Sidharta and Watie Moerany [19]. Even with the three times exhibitions and those of the Museum of Presidential Palaces of Yogyakarta and Bali, it cannot facilitate to Soekarno wishes for around 15.000 items of his art collections. Due to security reasons, all of Soekarno's art collections cannot be visited by the public.

The last research finding is a video model of the imaginary museum building, which contained Soekarno's Painting Collections series created based on the historical archives. The video model itself has a suitable requirement for 
millennials to access it everywhere and anytime easily. [20].

\section{LITERATURE REVIEW}

"De Tjolomadoe" museum's data was collected using qualitative methods. Both museums are created based on historical archives (intangible). "De Tjolomadoe" is a traditional museum. While the other is the imaginary virtual museum, which is mobile or can display its collections by using digital applications such as digital art, net art, environmental, virtual reality, and 3D of collections.

According to the traditional museum concepts, there is "The 10 Trends of Museum" that have changed the museum world [21], among others;

(1) Hybrid, the museum must create a 'Hybrid Spaces' to collaboration with other parties, for example, the Te Papa Museum's Learning Lab in New Zealand

(2) Instagram Ready, the museum must be arranged with attractive settings to be ready to air on Instagram screens; for example, The Ice Cream Museum in Los Angeles (April 2017), then in New York (June 2017)

(3) Well - Being, the museum must hold the feeling of Prosper Together. "Well-Being" with other art performances, for example, dances, songs, music, films

(4) Touchpoint, there is a Museum section that is permitted to be touch (can be by a replica) or something like a 'pop up' artifact as a supporter, for example, The Jewish Museum Frankfurt's Pop-Up Monument on the Willy-Brandt-Platz.

(5) Chatting, the conventional museum needs to be changed to have an area to keep in touch between visitors

(6) Social Justice. The museum needs to incorporate social media elements to be friendly to the millennial generation.

(7) New Realities, from Information to Experience. The museum dares to enter a 'novelty elements' in the museum.

(8) New Normal. The museum must be designed in new unique elements related to the hot issues that were initially taboo.

(9) Remapped. The museum must review the procedures for collections display related to hot issues/ trends.

(10) Agility is the New Stability. The museum must design the 'novelty' which reflects the agility

One of the future world-class museums based on "The 10 Trend of Museum" is Museum for the Future prepared by The Dubai Future Foundation, 2010 [22]. According to Rashid, the concept of the Museum of the Future is how to find goodness for the humanity by seeking to the future and attracts experts, decision-makers, entrepreneurs, and innovators to share insights and knowledge, including the robotic. Because the Museum for the Future is categorized into traditional museum/ physical museum building, so his statement has enriched a new discourse of a new museum definition. Due to its complexity, the museum was then making their highest effort in time-consuming, costly, and high technology to achieve it as a part of civilization.

On the other hand, the Indonesian Government needs to cut the time and budget to strengthen human resources. Related to creating a museum, thus it needs an innovative way to solve the human resources problems. One of them is by creating an imaginary or virtual museum to challenge the complexity of traditional museums. A virtual museum may adopt all of the ICOM criteria of the museum requirement by referring to "The 4P of Museums 2000 Concepts", among others; politics, people, professionals, and profit [23]. The museum concepts are compacted by focusing on the museum collections. There were problems to create the world-class traditional museum, among others; (a) real location, (b) budgeting, (c) time, (d) technology, (e) the political policy. According to the Author, an imaginary or virtual museum as a hybrid between digital application and architecture design is the best solution. By watching a video model, visitors can learn the painter's style in Soekarno's period. All of his paintings collections are done by Maestro Artists.

The video model was created based on architectural science but is not real to build. The imaginary building means only in imagination, not real. However, all collections are real based on archives and can be seen in digital applications. The imaginary museum building is created by the nature of architecture science. Architects can explore her/his ideas as free as possible because his/her designs are in imaginary categories. He/she may adopt many approaches to find the idea of "form" in the museum design case. Referring to the Derrida's theory in architecture, he stated: "...la structure même du dispositif architectural: séquence, sérialité ouverte, narrativité, cinématique, dramaturgie, choregraphie (...the structure of the architectural system is: sequence, open seriality, narrativity, cinematic, dramaturgy, choreography". Then, he declared trans-architecture or an architecture-event theory by guiding how to present the "event" by presenting a "wow effect" [24].

Related to "The 7 (Seven) New Trends In Museum Design" in 2019 [25], museums are rethinking the physical plant to carry out a new mission - to serve broader, morediverse public while staying afloat financially. Flynn stated that there was a reform of the museum visitor's mindset in thirty-five years ago. She stated that the role of the building envelope design is significant; besides, evaluation of the amount of parking, shop/ retail, café/restaurant space are needed. By creating an imaginary museum building, all of "The 7 (Seven) New Trends in Museum Design" can be accommodated. The idealistic of the design was visualized into the cyberspace. 


\section{METHOD AND FINDINGS}

\subsection{First Case "De Tjolomadoe" Museum}

The visit to "De Tjolomadoe" Museum of Surakarta is by referring to a phenomenology in Grounded Research [26]. As usual traditional museum, "De Tjolomadoe" has many artifacts related to the sugar factory process. "De Tjolomadoe" museum located inside the old building. The museum storyline starts from the zone of the biggest of archaeological giant machines. Visitors are invited to enjoy the sugar factory process by watching giant sugar roll mills that are still there. The sugar roll mills machines look like giant wheels located $2 / 3$ above the stage floor. Its dimension and uniqueness cause the museum ambiance to resemble the factory experience in the past. The whole story about suiker fabriek of Tjolomadoe itself is in a closed room. Images, drawing documents, photographs, archival data, text, and architectural models of the sugar factory are present. The former sugar factory "De Tjolomadoe" is living inside the museum entirely by the history of suiker fabriek of Tjolomadoe. The history started in the 1861s when the private sugar factory in Java island was built by Kanjeng Adipati Arya Mangkunegara IV until it was closed by the Indonesian Government in 1998. [27]. "De Tjolomadoe" is a traditional/ conventional museum located at the old sugar factory in Karanganyar of Central Java. It needs more than 1 hour from Soekarno-Hatta airport in Cengkareng. "De Tjolomadoe" is located at a strategic location near the Adisucipto Airport of Karanganyar. The spatial experiences inside "De Tjolomadoe" were described into the architectural analysis, among others; (a) location, (b) building façade, (c) architectural space, (c) Storylines (d) collections.

The old building was changed after the Adaptive Reuse held in the 2017s. For a glance (a) the museum location is in a strategic place, (b) "De Tjolomadoe" has an attractive building façade, especially the old chimney of the sugar factory, (c) the architectural space the museum is moderate because it has many museum collections, among other; an architecture model of suiker fabriek of Tjolomadoe, photograph, original architectural drawing, archives, graphics, audiovisual facility, (c) the museum storylines were created in an excellent flow, (d) the iconic collections of the old sugar factory machines are the best. The whole experience at "De Tjolomadoe" encourages 'a new ambiance'. Surrounded by the gigantic scale of the sugar machines factories inside the building, causing visitors to feel the smallest, shocked, feeling happy, and fun. "De Tjolomadoe" museum was trying to connect distances and trajectories of the Colonial era by exposing the archeological artifacts and textual descriptions.

However, the findings of" De Tjolomadoe" Museum was not awakening an emotional nuances. The original aesthetic moment of suiker fabriek cannot appear due to the limitation of technology in the $1861 \mathrm{~s}$ to record the memories: (a) the museum has not yet explored the role of Kanjeng Adipati Arya Mangkunegara IV in his story and his factory (b) museum may explore the untold story of the actor of the old Tjolomadoe, known as the Prince's wife, Nyi Pulungsih. Because of her, the sugar factory could create community wealth. Nevertheless, "De Tjolomadoe" tries to attract the millennials generation by inserting the "Glow in the Dark" computerized effect.

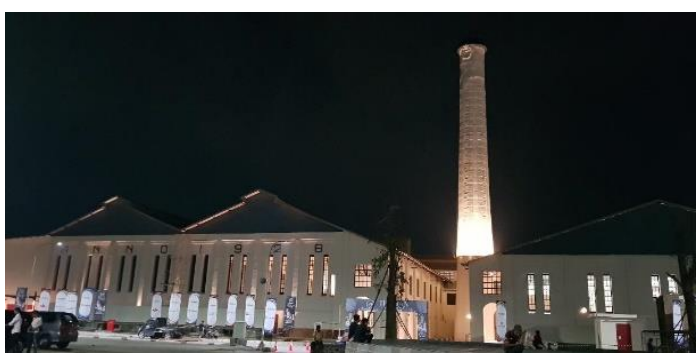

Figure 1 The iconic chimney of "De Tjolomadoe"

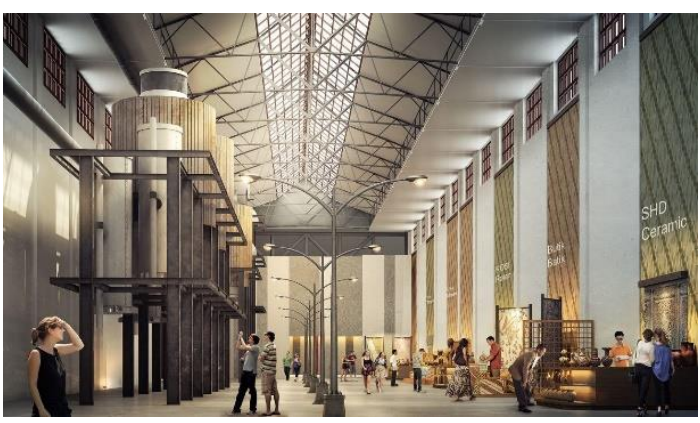

Figure 2 "De Tjolomadoe" in architectural images

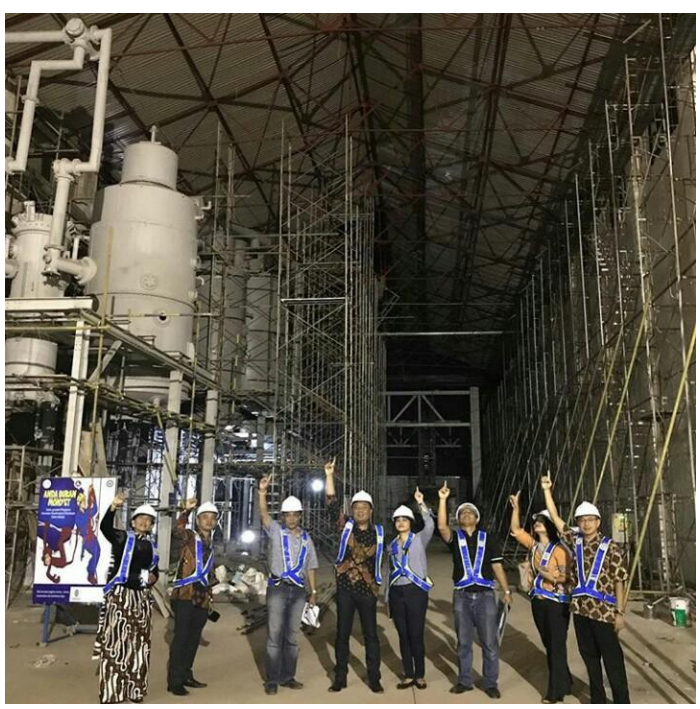

Figure 3 "De Tjolomadoe" during construction 


\subsection{Second Case: Soekarno's Virtual Museum: a Video of the Imaginary Museum}

The second case is a video to show an imaginary museum designed based on architectural science using a digital application. The 3D video of Lumion, namely "Soekarno's Virtual Museum": A Painting Series Collections, is a pilot project of a virtual museum. The video duration is around 10 (ten) minutes. The design process of the video, among others; (a) Data Collection, (b) Analysis Phase, (c) Architectural Animation (d) Production Stage, (e) Production Test Phase, (e) Finalization Stage. After preparing an architectural standard of the building that took place, an imaginary site, a museum storyline, and the design concept, we continue by creating the 3D video using Lumion.

After watching a video of "Soekarno's Virtual Museum": A Painting series Collections for a glace of experiences: (a) the imaginary museum building took place at a lovely location. It is located at the sacred beach, one of the best panoramic views is filled with high waves as a symbol of Indonesia's struggle, and related with the myth of "Ratu Kidul" - the South Beach's Queen. (b) the building 'form' looks like a piece of a White Lotus flower - bunga Teratai Putih - a sacred object of the Javanese Kingdom on the Hindus temple. The flower is pure white. The architectonic design of the imaginary museum is modified by referring to 'Metaphor to Natural and Cultural' - as one of "The Postmodern Architecture's Theories of Jenck". The imaginary museum building was 'floating' on the sacred beach that Soekarno loved, in the South Beach - Laut Selatan. The sacred beach has one of the best panorama filled with high waves as a symbol of Indonesia's struggle, and related to the myth of "Ratu Kidul" - the South Beach's Queen. (c) the museum storylines start from the Soekarno himself and flowing to the five-book collection series, (d) the painting collections of maestro artists are very wonderful virtually.

Table 1 Contents of Soekarno's painting collection books

\begin{tabular}{|c|c|c|c|}
\hline \multirow{2}{*}{$\begin{array}{l}\text { Book } \\
\text { Number }\end{array}$} & The Soekarno's Paiting Collection Book Series, Curated by Lee Man Fong, 1964 \\
\cline { 2 - 4 } & Indonesian Painters & Other Country Painters & Total \\
\hline 1 & 61 pieces & 40 pieces & 101 pieces \\
\hline 2 & 51 pieces & 49 pieces & 100 pieces \\
\hline 3 & 55 pieces & 45 pieces & 100 pieces \\
\hline 4 & 51 pieces & 49 pieces & 100 pieces \\
\hline 5 & Sculptures & Ceramics/ Porcelains & Total \\
\hline & 82 pieces & 85 pieces & 167 pieces \\
\hline
\end{tabular}
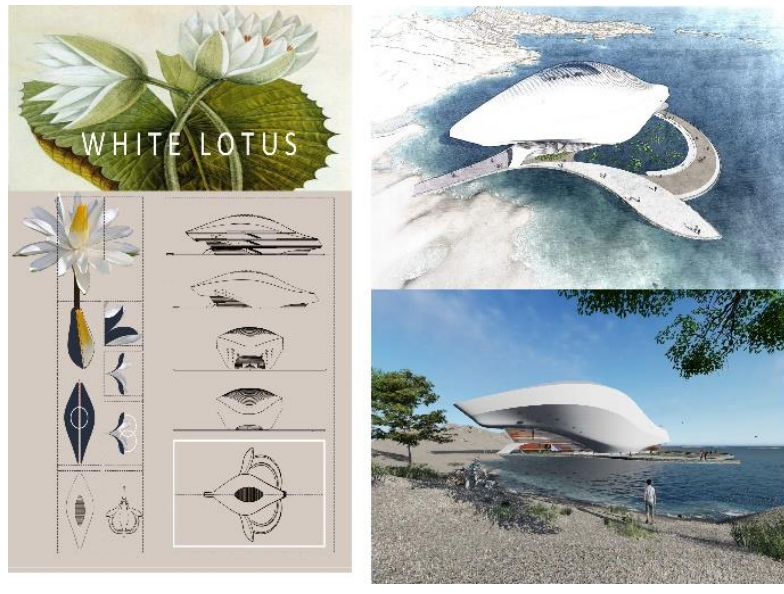

Figure 4 The imaginary building is modified by a piece of a White Lotus, a sacred object of the Javanese Kingdom on the Hindus temple

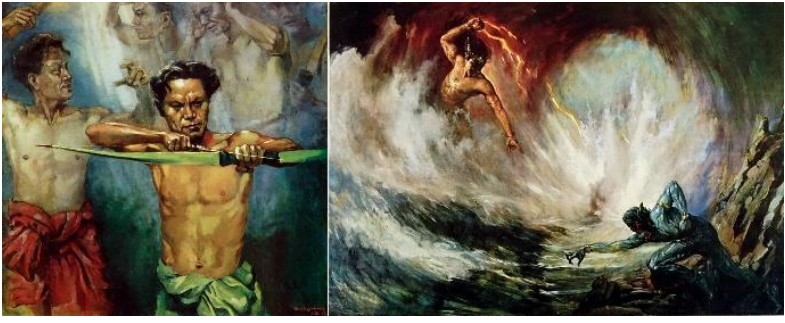

Figure 5 The Soekarno's painting collections of book one
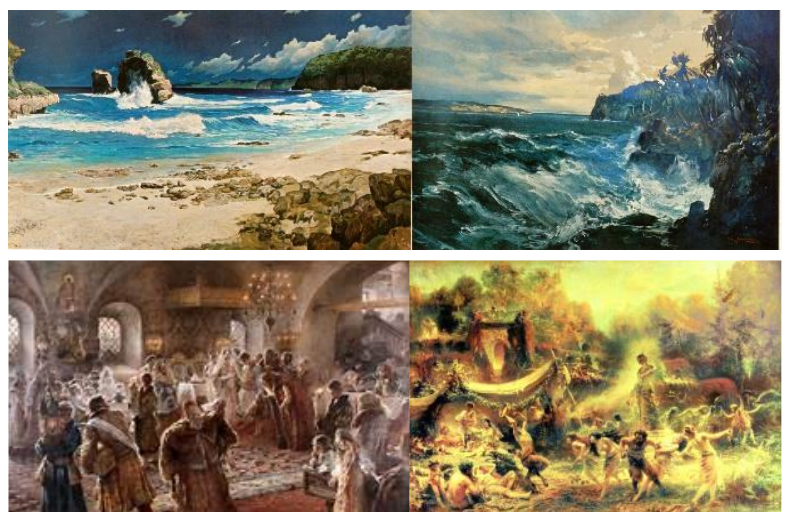


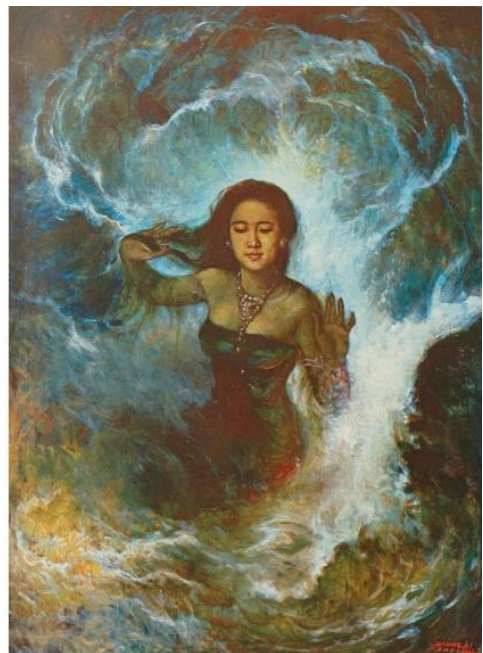

Figure 6 The Soekarno's painting collections of book two
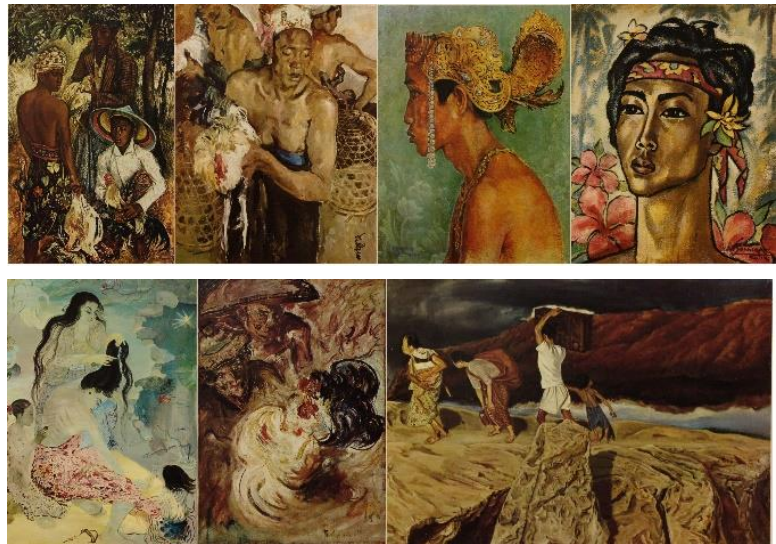

Figure 7 The Soekarno's painting collections of book three

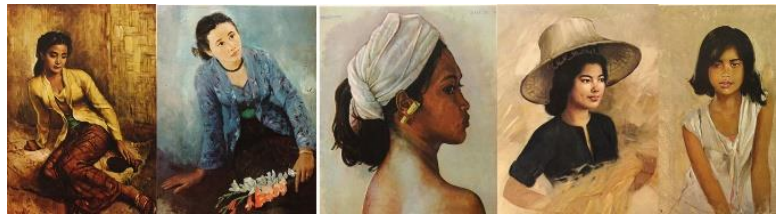

Figure 8 The Soekarno's painting collections of book four

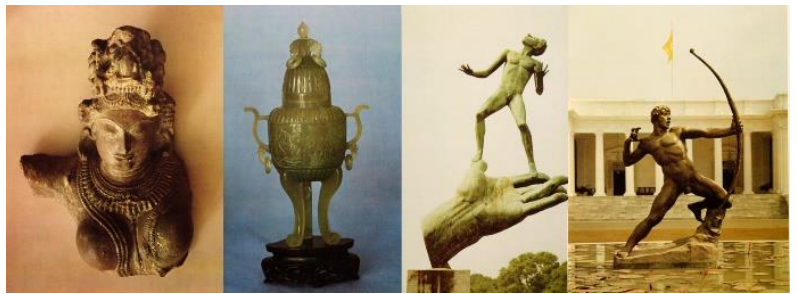

Figure 9 The Soekarno's painting collections of book five

\section{CONCLUSION}

A virtual museum can resolve some significant problems, including; (a) limitation of space, (b) limitation of budget, (c) limitation of real collections, (d) limitation of times. An imaginary museum that we prepared has all requirements of the building design process, including the site, room programming, floor plan, section, façade, construction, and interior lay out of the museum exhibition.

"De Tjolomadoe" Museum was created on the heritage building as well as a prominent place as the former sugar factory. It needs extraordinary effort, budget, time, artifact collections, policy, among others. On the other hand, the imaginary building of Virtual Museum by the digital application can be the solution to cut the extraordinary effort. By creating an imaginary museum building, all the messages to lead the millennial educate in art painting can take place. The video can be uploaded on social media. By watching its video on social media, then millennial generation can learn, among others, (a) architectural design, (b) the rare collections, (c) cut off time, (d) cut off budget, (e) feeling happy and fun. A virtual museum of Soekarno's Painting Collections Series is a video model created based on multidisciplinary disciplines of historical archives, architectural science, and digital application. By watching this video of an imaginary museum building, the public can easily access the Soekarno's legacy. There is no more security concern to visit the Soekarno's collections because the imaginary museum building of Soekarno's legacy can be visited everywhere and every time.

\section{ACKNOWLEDGMENT}

We would like to thank (1) Soekarno Foundation - Yayasan Bung Karno for giving permission the Soekarno's Painting Collections Books as the basis of the virtual museum, (2) LPPM of Universitas Pancasila, (3) Julius Andy and Ruby Chrissandy for images reproduction of the books, (4) The Pura Mangkunegaran, (5) PT PP Property Tbk.

\section{REFERENCES}

[1] Virtual Tour of Museum National of Indonesia http://museumnasional.indonesiaheritage.org/

[2] Dictionary.com https://www.dictionary.com/

[3] Ardhiati, Yuke. "A" New Museum of Batik: An Architecture of "Showing Off". Journal of Civil Engineering and Architecture, 11 (2017) pp. 305-312

[4] Ardhiati, Yuke. The Monograph of the Museum Buildings, 2019

[5] Ibid [3]. 
[6] Ibid [3].

[7] De Tjolomadoe. https://www.detjolomadoe.com/

[8] The Republic of Indonesian Law. No. 11, 2010 about Cultural Heritage

[9] Ardhiati, Yuke. De Tjolomadoe: Adaptive Reuse Bangunan Cagar Budaya. Jakarta, Wastu Adicitta, 2018

[10] Soerabaiasch-Handelsblaad, 19 April 1937.

[11] De Tjolomadoe Museum, 2019.

[12] Soerat Koeasa Istimewa Archives of PT PP Property, 2016.

[13] Riyanto, Eddy. Perubahan Sosial Ekonomi Masyarakat Colomadu Akibat Peniduran Pabrik Gula Colomadu Tahun 1998-2007, Magister Tesis of UNS, 2010.

[14] Adams, Cindy. Sukarno an Autobiography as told to Cindy Adams. Kansas City, New York: Indiana Polis, 1965

[15] Man Fong, Lee (ed). Paintings and Statues from The Collection of President Sukarno of The Republic of Indonesia, Book 1-5, Tokyo-Jepang: PT. Pertjetakan Toppan, 1964

[16] Ardhiati, Yuke. Architectonics: Design of the $\mathrm{Nu}$ Art Museum in Bandung. The International Journal of Architectonic, Spatial, and Environmental Design, Volume 12 Issue 3, pp.17-28, September 2018

[17] Susanto, Mikke and Zaelani, Rizki A. 1771: The Brush strokes of the Struggle for Independence", The Ministry of Presidential Secretary, Jakarta, 2016.

[18] Hasan, Asikin; Sidharta, Amir; Susanto, Mikke and Texania, Selly. Our Motherland's Melody, The Ministry of Presidential Secretary, Jakarta 2017

[19] Sidharta, Amir, The Ministry of Presidential Secretary, Jakarta 2018

[20] Ardhiati, Yuke. A Video Concept of the Soekarno's Virtual Museum: Painting Collections Series, 2019

[21] Dubai Future Foundation. Museum of The Future 2020. https://www.dubaifuture.gov.ae/ourinitiatives/museum-of-the-future/

[22] Museum Tech Trends. 10 Top Museums in 2019 https://medium.com/museum-tech-trends/top-10museum-trends-in-2019-3c5582ed8253
[23] Boylan, P., ed. Museum 2000: Politics, People, Professionals, and Profit. London and New York: Routledge. 1992.

[24] Derrida, J. 1986. "Point de Folie-Maintenant l'Architecture." In Essay accompanying the portfolio Tschumi, Bernard. La Case Vide: La Villette, trans. by Linker, K. London: Architectural Association. Accessed January 1, 2017. http://isites.harvard.edu/fs/docs/icb.topic 136722.files/Week_spacing/Derrida_Point_du_Folie.pd f.

[25] Flynn, Larry. The 7 New Trends In Museum Design, 2002. https://www.bdcnetwork.com/7-newtrends-museum-design

[26] Ardhiati, Yuke. Grounded Theory untuk Arsitektur, Seni dan Desain. Jakarta, Wastu Adicitta, 2018

[27] Ardhiati, Yuke. De Tjolomadoe: Adaptive Reuse Bangunan Cagar Budaya. Jakarta, Wastu Adicitta, 2018

[28] Jencks, C.A. "Post-Modern Architecture" From the Language of Postmodern Architecture. Academy Editions, London and Rizzoli, New York, 1997 